\title{
Sleep Duration and the Risk of Metabolic Syndrome: a Systematic Review and Meta-analysis
}

1 Jianian Hua ${ }^{13, \#}$, Hezi Jiang ${ }^{23, \#}$, Qi Fang ${ }^{1, *}$

$2{ }^{1}$ Department of Neurology, The First Affiliated Hospital of Soochow University, Suzhou, 215006,

3 Jiangsu Province, China.

$4 \quad{ }^{2}$ Department of Cardiology, The First Affiliated Hospital of Soochow University, Suzhou, China.

$5{ }^{3}$ Medical College of Soochow University, Suzhou 215123, PR China.

6 "These authors contributed equally.

7 *Corresponding author

$8 \quad$ Qi Fang

9 fangqi_008@126.com

10 
medRxiv preprint doi: https://doi.org/10.1101/2020.08.30.20184747; this version posted September 3, 2020. The copyright holder for this preprint (which was not certified by peer review) is the author/funder, who has granted medRxiv a license to display the preprint in perpetuity.

All rights reserved. No reuse allowed without permission.

\section{Abstract}

35 Objective: Epidemiologic studies have reported inconsistent findings about the association between

36 sleep duration and metabolic syndrome. We aimed to clarify this association by method of meta37 analysis.

38 Methods: Medline, Embase, CINAHL and PsycINFO databases were searched from inception to 39 May 2020. We collected data from 235,895 participants from 9 prospective cohort studies, and 40340,492 participants from 26 cross-sectional studies. Risk ratios (RR) or odds ratios (OR) were 41 calculated separately for cohort studies and cross-sectional studies, through meta-analysis of adjusted 42 data from individual studies.

43 Results: For cohort studies, short sleep duration was associated with an increased risk of metabolic 44 syndrome (RR, 1.15; 95\% CI, 1.05-1.25). Long sleep duration was not associated with new onset 45 metabolic syndrome (RR, 1.02, 0.85-1.18). For cross-sectional studies, both short (OR, 1.12, 95\% CI, 46 1.08-1.18) and long (OR, 1.06, 1.01-1.11) sleep duration was associated with high prevalence of 47 metabolic syndrome.

48 Conclusions: Only short sleep duration was associated with an increased risk of metabolic syndrome. 49 Future studies should address whether the association is casual and modifiable.

50 Keywords: sleep duration, metabolic syndrome, cohort study, meta-regression, meta-analysis 51 


\section{$71 \quad 1 \quad$ Introduction}

72 Metabolic syndrome is a cluster of disorders that occur together, and it is defined as a condition 73 consisting of at least three of the following: hypertension, high blood sugar, excessive waist 74 circumference, higher triglyceride (TG) levels or low high-density cholesterol (HDL) levels. 75 Metabolic syndrome is associated with adverse cardiovascular events, even after adjusted for diabetes and obesity ${ }^{1,2}$. Meanwhile, the prevalence of metabolic syndrome in America is up to $33 \%{ }^{3}$. Recently, growing concern has been paid to the modifiable risk factors of metabolic syndrome ${ }^{4}$. Abnormal sleep duration is known to increase the risk of a serious health outcomes, including mortality, diabetes and cardiovascular disease ${ }^{5,6}$. Therefore, both sleep and metabolic syndrome increase the risk of cardiovascular event. However, whether abnormal sleep duration increase the risk of metabolic syndrome remained controversial. Several meta-analyses have reported the association between sleep duration and metabolic syndrome ${ }^{7-9}$. However, none of the studies assessed the association in a prospective cohort design, which has less substantial bias could provide stronger support for causality $6,10,11$

85 Therefore, we conducted a systemic review and meta-analysis to: (1) examine all prospective cohort studies that have assessed the effect of sleep duration on the future risk of metabolic syndrome; (2) conduct an updated meta-analysis to examine the cross-sectional association.

\section{Materials and Methods}

89 We performed this study according to Preferred Reporting Items for Systematic Reviews and Meta90 Analysis (PRISMA) guidelines (Table S1).

91 Two independent researchers (JNH and HZJ) separately assessed the eligibility, extracted data, and 92 checked the quality of the included studies. Any disagreement in screening the articles were resolved 93 through discussion between these two, with adjudication by a third research (QF) if disagreements 94 persisted.

\section{$95 \quad 2.1 \quad$ Search strategy}

96 A systematic search was conducted in Medline, Embase, CINAHL and PsycINFO from inception to 97 May 2020. We used the following search terms: (1) "sleep hour" OR "sleeping hour" OR "hours of 98 sleep" OR "sleep duration" OR "sleep time" OR "sleep length" OR "sleep period" OR "sleeping time" 99 OR "sleep span"; (2)"metabolic syndrome" or "MetS" or "MS" or "syndrome X" or "cardiometabolic 100 risk factor" or "insulin resistance syndrome". Algorithms combining the two sets of search terms 101 were applied.

\section{$102 \quad \mathbf{2 . 2}$ Study selection}


103 Studies that examined the relationship between sleep duration and metabolic syndrome were 104 screened for eligibility, without language restriction. The inclusion criteria were: (1) the research was 105 a cohort or a cross-sectional study; (2) the research compared individuals with "unnormal" and 106 "normal" sleep duration on the outcome of metabolic syndrome. If one or more articles reported data 107 from one study, the article with the largest sample size and the best design was included.

108 We analyzed cohort studies and cross-sectional studies separately in all analysis due to the following reasons. First, cross-sectional study could not establish a causal relationship, and it only reflected the association between sleep duration and the prevalence of metabolic syndrome ${ }^{11}$. Second, the nonexposed prevalence of metabolic syndrome was higher than $20 \%{ }^{12}$, odds ratios (OR) could not be 112 regarded as risk ratio $(\mathrm{RR})^{13}$.

113 The inclusion of studies was conducted in two stages: (1) screening of the title and abstract and (2) 114 screening of the full text.

\subsection{Data extraction}

116 The following characteristics were extracted from each eligible study: author name and publication year, study type, study location (country and continent), sample size, participants' characteristics (age range, mean age and sex composition), exposure and outcome assessment (sleep assessment, metabolic syndrome measures and definition of long or short sleep duration) and main results.

120 Since definition of sleep duration varies among studies ${ }^{14}$, the three categories of sleep duration (short,

121 long and normal) was extracted by one of the following two ways. For some papers, sleep duration

122 was already divided into three categories based on cultures and ethnicities. For others, in which sleep

123 duration was divided into more than three groups, short or long sleep duration was defined as the 124 shortest or longest group reported in the article 6 . With regard to the main results, the adjusted 125 estimates that reflected the most comprehensive control were extracted.

126 Data were extracted by two investigators (JNH and HZJ) independently. Disagreement in screening 127 the articles was resolved by discussion between the two investigators. Consultation from a third 128 investigator $(\mathrm{QF})$ was acquired if necessary.

\subsection{Exposure and outcome measures}

130 With regard to the measurements of nocturnal sleep duration, two studies used objective 131 measurement, while others used interview or questionnaire.

132 The diagnostic criteria of metabolic syndrome (MetS) varied between studies. 10 studies used the

133 Third Report of the National Cholesterol Education Program's Adult Treatment Panel III (NECP 134 ATP-III); 4 studies used modified NECP ATP-III; 14 studies used the American Heart 135 Association/National Heart Lung and Blood Institute (AHA-NHLBI); 3 studies used the International 136 Diabetes Federation (IDF) ${ }^{8} ; 5$ studies used other criteria. 


\subsection{Quality appraisal}

139 The quality of all studies was evaluated by Newcastle-Ottawa Quality Assessment Scale (NOS) ${ }^{15}$.

140 The total score ranged from 0-9 scores. For outcome category and comparability category, all the

141 studies had similar quality. The difference between studies lied in the study design category (Table

142 S3).

\section{$143 \quad 2.6 \quad$ Data analysis}

144 We conducted all the following analysis separately for cohort studies and cross-sectional studies, and

145 for study-specific short and long sleep duration, respectively.

146 In analysis of cohort studies, hazard ratios (HRs) were regarded as risk ratios (RRs). For studies

147 which provided only odds ratios (ORs), we calculated RRs by using the ORs and control event rates 148 (CERs) in normal sleepers. Using random-effect models, we estimated the pooled RR and 95\% CI.

149 With regard to cross-sectional studies, we calculated the pooled OR and 95\% CI using random-effect 150 models.

151 Heterogeneity between the studies was assessed using Cochran $\mathrm{Q}$ statistics $(\mathrm{P}<0.1$ indicates 152 statistically significant heterogeneity) and $I^{2}$ statistic $\left(I^{2}>50 \%\right.$ indicates statistically significant 153 heterogeneity) ${ }^{16}$. To examine publication bias, we used a funnel plot, the Egger regression test, and 154 the Begg and Mazumdar test ${ }^{17,18}$. "Trim and fill" method was used to adjust the funnel plot, and recalculated the results ${ }^{19,20}$. Sensitivity analysis was performed by excluding one study at a time to test the robustness of the pooled estimates.

157 Subgroup analysis was conducted to explore the potential heterogeneity among cross-sectional 158 studies. We used $\mathrm{z}$ test to compare summary estimates of each subgroups ${ }^{21}$. Univariate and 159 multivariate meta-regression were used to study the effect of possible influential confounders, such 160 as definition of sleep duration and study quality. For cohort studies, subgroup analysis and meta161 regression was not performed considering the small number of datasets included in the meta-analysis. 162 All statistical analysis was performed by R-3.4.3 ${ }^{20}$ and Stata 15.1 (Stata Corp, College Station, TX).

\section{Results}

\section{$164 \quad 3.1 \quad$ Search results}

165 The initial electronic search yielded 1140 articles, among which 789 were reviewed by title and abstract. 127 full-texts were retrieved. 35 studies were included in the final analysis (Figure 1).

\section{$167 \quad 3.2 \quad$ Characteristics of study samples}

168 We identified nine prospective cohort studies that examined the association between sleep duration 169 and the incident risk of metabolic syndrome, in a total of 235,895 participants. The sample size 170 ranged from 293 to 162,121 . The mean follow-up duration ranged from 2 to 8 years (Table 1). 
171 Another twenty-six studies were cross-sectional studies, included a total of 340,492 individuals. The 172 sample size ranged from 263 to 88,678 (Table S2).

173 Table 1 and Table S2 presented the characteristics of the all 35 studies. The individuals all aged 174 above 18 year. The mean (SD) age of the individuals ranged from 31 (8.7) to 67.6 (7.3) years. The 175 studies were conducted in five continents, while many of them were from Asia. The definitions of 176 short or long sleep duration varied between studies. About 75\% studies defined "short sleep duration"

177 as $<6$ or $<7 \mathrm{~h}$, and about $80 \%$ studies defined "long sleep duration" as $>8$ or $>9 \mathrm{~h}$.

\section{$178 \quad 3.3 \quad$ Primary analysis}

\section{$179 \quad$ 3.3.1 Sleep duration and the risk of metabolic syndrome}

180 Compared with moderate sleep duration, short sleep duration was associated with a statistically 181 significant increase in new onset metabolic syndrome, with an RR of 1.15 (95\% CI=1.05-1.25, $182 \mathrm{P}<0.001, \mathrm{I}^{2}=63.6 \%, \mathrm{~N}$ of datasets=11; Figure $2 \mathrm{~A}$ ).

183 Compared with moderate sleep duration, the association between long sleep duration and risk of metabolic syndrome was not statistically significant, with an RR of 1.02 (95\% $\mathrm{CI}=0.85-1.18$, $\mathrm{P}=0.491, \mathrm{I}^{2}=38.0 \%, \mathrm{~N}=9$; Figure $\left.2 \mathrm{~B}\right)$, using random effect model. The RR reduced to $0.94(95 \%$ $\mathrm{CI}=0.89-0.99, \mathrm{P}=0.050, \mathrm{I}^{2}=38.0 \%, \mathrm{~N}=9$ ), using fixed effect model.

187 Among the seven studies that examined the effect of long sleep duration, six did not observe a 188 significant association. Only Li X. found that long sleep duration increased the risk of metabolic syndrome among men (adjusted $\mathrm{HR}=1.96,95 \% \mathrm{CI}=1.35-2.85$ ).

\subsubsection{Sleep duration and the prevalence of metabolic syndrome}

191 Compared with moderate sleepers, people with short or long sleep duration had a higher prevalence of metabolic syndrome. The pooled OR of metabolic syndrome in short sleepers compared to moderate sleepers was 1.06 (95\% $\mathrm{CI}=1.01-1.11, \mathrm{P}<0.001, \mathrm{I}^{2}=66.5 \%, \mathrm{~N}=32$; Figure $\left.3 \mathrm{~A}\right)$. The pooled

194 OR of metabolic syndrome in long sleepers compared to moderate sleepers was 1.11 (95\% CI=1.04$1951.17, \mathrm{P}<0.001, \mathrm{I}^{2}=73.8 \%, \mathrm{~N}=31$; Figure 3B).

\subsection{Possible publication bias for primary analysis}

197 Results of Begg and Mazumdar and Egger test were shown in Table S4. No significant publication 198 bias was observed. "Trim and fill" test indicated that the primary results was still significant after the 199 missing studies were filled in (Table S5). Visual inspection of the funnel plots also did not reveal 200 apparent publication bias (Figures not shown).

\subsection{Subgroup analysis}


Subgroup analysis of the cross-sectional studies were shown in Table 2. No significant subgroup difference was found for gender, continent, and definition of abnormal sleep duration. There were statistically significant subgroup effects $(\mathrm{P}<0.05$ for heterogeneity between groups). For short sleepers, the specific domains were study population, sleep measurement, measures of metabolic syndrome and sample size. For long sleepers, the specific domains were sleep measurement, long sleep duration, measures of metabolic syndrome, sample size, and study quality. However, there was still unexplained heterogeneity within some subgroups. Therefore, the subgroup couldn't fully explain the overall heterogeneity.

210 For short sleepers, hospital-based participants had a higher OR than the community-based. With 211 regard to definition of short sleep duration, there was a tendency that lower duration was associated 212 with higher OR. Nevertheless, the P value was not significant.

213 For long sleepers, compared with "NECP" group, "modified-NECP" group had higher OR. Studies 214 with more participants or higher quality had lower OR.

\section{$215 \quad 3.6 \quad$ Sensitivity analysis}

216 None of the sensitivity analysis substantially altered the effect of both long and short sleep duration 217 on metabolic syndrome (Figure S1).

\subsection{Meta-regression}

219 With regard to cross-sectional studies, a multivariate meta-regression analysis (Table 3) was conducted to examine the potential influence of different factors on the natural logarithm of the OR of short or long sleep duration with prevalence of MetS. For short sleepers, shorter definition of duration was associated with higher $\mathrm{OR}(\mathrm{P}=0.011$ for multivariable test, and $\mathrm{P}=0.099$ for univariable test). Higher study quality was associated with lower $\mathrm{OR}(\mathrm{P}=0.010$ for univariable test and $\mathrm{P}=0.033$ for multivariable test). The effect of mean age was significant. However, the clinical effect (coef=0.01) was little. For long sleepers, none of the study factors was significant.

\section{Discussion}

To our knowledge, this was the first meta-analysis on the association between sleep duration and the risk of metabolic syndrome. Our study indicated that short sleep duration correlated with an increase in the risk of metabolic syndrome. Long duration was not statistically associated with the risk of metabolic syndrome. With regard to cross-sectional studies, both short and long sleep duration was associated with higher prevalence of metabolic syndrome.

232 Our results differed from that of three previous meta-analysis, which reported the association between sleep duration and metabolic syndrome. Limited by sample size, the three studies did not distinguish cross-sectional studies and cohort studies in the main outcome. Ju 2013 and Iftikhar 2015 
both short and long sleep duration to metabolic syndrome ${ }^{9}$. Moreover, we observed narrower confidence intervals, which might be due to our higher number of included datasets. Nowadays, a growing number of articles reported an inverted-U shaped association between sleep duration and health outcomes, including metabolic syndrome ${ }^{22}$. Our findings suggested that long sleep duration might have no effect.

241 Compared with the previous studies, we further conducted comprehensive sub-group analysis and 242 meta-regression for cross-sectional studies. In subgroup analysis, using $\mathrm{z}$ test, we found no 243 statistically significant differences in subgroups of sex, continent, and sleep measurement. For short sleepers, hospital-based participants had a higher prevalence than community-based participants, which was consistent with a previous meta-analysis. One possible reason was that people in hospital had poor health conditions. The results of subgroup analysis and meta-regression showed that studies with high quality or larger sample size had smaller risk estimates. In multivariable meta-regression, shorter sleep duration was linearly associated with higher prevalence of metabolic syndrome. Longer sleep duration had no linear association. This "J-shaped" association was not consistent with the "Ushaped" association between sleep duration reported in many articles ${ }^{22}$. However, we thought this was not contradictory. In the meta-regression, "sleep duration" was a cut-off point defined by different authors from different ethnicities; and in one specific study, the author calculated the association among participants from a same ethnic.

Several mechanisms linked sleep duration to metabolic syndrome. Short sleep duration could lead to the following endocrine changes, by affecting carbohydrate metabolism, hypothalamo-pituitaryadrenal axis and sympathetic activity. Decreased glucose tolerance and insulin sensitivity would raise the glucose levels; increased levels of ghrelin, decreased levels of leptin and increased appetite correlated with higher waist circumstance; increased cortisol concentrations were associated with higher blood pressure ${ }^{23,24}$. Short sleepers tended to have low-grade inflammation. Elevated levels of high-sensitivity C-reactive protein and IL-6 correlated with cardiovascular events ${ }^{25}$. Long sleep duration was linked to sleep fragmentation, which would cause plenty of health outcomes, including metabolic change $\mathrm{e}^{26}$. Long sleepers also have less time to take excise, which might contribute to the association $^{27}$. Both short and long sleep duration had bidirectional association with circadian rhythm, which is a risk factor for metabolic disorders ${ }^{28,29}$. Despite these mechanisms which could explain the association, whether sleep duration was a causal risk factor for metabolic syndrome was still not sure $^{30}$. Cohort studies still could not provide a causal result, though they have more power than crosssectional studies. To prove a causal relationship, we need further examine the effect of changes in sleep duration $^{31}$, and product Mendelian randomization study, a method using measured variation in genes.

Our meta-analysis summarized the currently evidence of the association between abnormal sleep duration and the risk of metabolic syndrome, and indicated that short sleep duration was a risk factor for new onset metabolic syndrome. Strength of our study were the comprehensive search and strict inclusion criteria. However, there were some limitations that should be taken into consideration. First, 
274 the sleep categories varied between studies. There was no unified standard for definition of abnormal 275 sleep duration. Second, the estimates of relative risk had less accuracy than that in the individual 276 patient data meta-analysis. Third, we only included nine cohort studies, which prevent us from

277 conducting further research, such as subgroup analysis and meta-regression. Fourth, only two studies 278 used objective sleep measurement. More studies based on the objective measurement are needed in 279 the future.

\section{Conclusions}

281 Both short and long sleep duration was associated with high prevalence of metabolic syndrome cross282 sectionally. Short sleep duration, rather than long sleep duration, was associated with a significant 283 increase in risk for metabolic syndrome. Sufficient sleep duration should be recommended to prevent 284 metabolic syndrome.

285

\section{$286 \quad 6 \quad$ Author contributions}

287 Qi Fang and Jianian Hua contributed to the conception and design of the study. Jianian Hua 288 organized the database. Jianian Hua and Hezi Jiang performed the statistical analysis. Jianian Hua 289 wrote the first draft of the manuscript. Qi Fang and Hezi Jiang reviewed the manuscript. All authors 290 approved the final version of the paper.

\section{$291 \quad 7 \quad$ Funding}

292 This study was not supported by any funding.

\section{Conflicts of interest}

294 The authors declare that the research was conducted in the absence of any commercial or financial 295 relationships that could be construed as a potential conflict of interest.

\section{Preprint}


$298 \quad 10.1$ Table 1. Characteristics of cohort studies

299

\begin{tabular}{|c|c|c|c|c|c|c|c|c|c|c|c|}
\hline \multirow[t]{4}{*}{ Author, Year } & \multirow{4}{*}{$\begin{array}{l}\text { Study type } \\
\text { (follow-up } \\
\text { time) }\end{array}$} & \multirow{4}{*}{$\begin{array}{l}\text { Country, } \\
\text { Continent }\end{array}$} & \multirow{4}{*}{$\begin{array}{l}\text { Sample } \\
\text { size }\end{array}$} & \multirow{4}{*}{$\begin{array}{l}\text { Mean age } \pm \\
S D \text {, range }\end{array}$} & \multirow[t]{4}{*}{ Male $\%$} & \multicolumn{2}{|c|}{ Study population } & \multirow{4}{*}{$\begin{array}{l}\text { Sleep } \\
\text { meausrement }\end{array}$} & \multirow{4}{*}{$\begin{array}{l}\text { Metabolic } \\
\text { syndrome } \\
\text { measurement }\end{array}$} & \multirow{4}{*}{$\begin{array}{l}\text { Sleep } \\
\text { (h) }\end{array}$} & \multirow{4}{*}{$\begin{array}{l}\text { Main findings reported } \\
\text { in original articles: } \\
\text { Adjusted } \\
\text { HR/RR/OR }(95 \% \mathrm{CI})\end{array}$} \\
\hline & & & & & & & & & & & \\
\hline & & & & & & & & & & & \\
\hline & & & & & & & & & & & \\
\hline \multirow{3}{*}{$\begin{array}{l}\text { Choi, } 2011 \\
(\mathrm{male})^{32}\end{array}$} & Cohort & Korea & 2093 & $40-55$ & 0 & Community & & Interview & NECP ATP-III & $<6$ & aHR 1.80(1.06-3.05) \\
\hline & $(2-4)$ & Asia & & & & & & & & $6-8$ & Ref. \\
\hline & & & & & & & & & & $\geq 10$ & aHR 1.57(0.61-4.01) \\
\hline \multirow{3}{*}{$\begin{array}{l}\text { Choi, } 2011 \\
\text { (female) }\end{array}$} & Cohort & Korea & 2133 & $40-55$ & 100 & Community & & Interview & NECP ATP-III & $<6$ & aHR 0.62(0.24-1.64) \\
\hline & $(2-4)$ & Asia & & & & & & & & 6-8 & Ref. \\
\hline & & & & & & & & & & $\geq 10$ & aHR $1.66(0.71-3.88)$ \\
\hline \multirow{2}{*}{$\begin{array}{l}\text { Otsuka, } \\
2011^{33}\end{array}$} & Cohort & Japan & 2090 & 44.6 & 47.2 & Community & & Questionnaire & Japanese criteria & $\leq 5$ & aHR 3.18 (1.52-6.64) \\
\hline & (3.7) & Asia & & $35-63$ & & & & & & $>6$ & Ref. \\
\hline \multirow{3}{*}{$\begin{array}{l}\text { Chaput, } \\
2013^{34}\end{array}$} & Cohort & Canada & 293 & $39.2 \pm 14.3$ & NA & Community & & Questionnaire & AHA-NHLBI & $\leq 6$ & aHR 1.82(1.16-4.79) \\
\hline & (6) & North America & & $18-65$ & & & & & & $7-8$ & Ref. \\
\hline & & & & & & & & & & $\geq 9$ & aHR 1.13(0.58-1.98) \\
\hline \multirow[t]{3}{*}{ Kim, $2015^{35}$} & Cohort & Korea & 2579 & $54.1 \pm 8.3$ & 34.5 & Company & or & Interview & AHA-NHLBI & $<6$ & aOR 1.41(1.06-1.88) \\
\hline & (2.6) & Asia & & $\geq 20$ & & office & & & & $7-8$ & Ref. \\
\hline & & & & & & & & & & $\geq 10$ & aOR $0.68(0.39-1.17)$ \\
\hline \multirow{3}{*}{$\begin{array}{l}\mathrm{Li}, 2015 \\
(\text { male })^{36}\end{array}$} & Cohort & China & 4774 for all & $30-65$ & 100 & Community & & Questionnaire & AHA-NHLBI & $<6$ & aRR 1.87 (1.51-2.30) \\
\hline & (4.4) & Asia & & & & & & & & $7-8$ & Ref. \\
\hline & & & & & & & & & & $>8$ & aRR $1.96(1.35-2.85)$ \\
\hline \multirow{3}{*}{$\begin{array}{l}\mathrm{Li}, 2015 \\
(\text { female })^{36}\end{array}$} & Cohort & China & 4774 for all & $30-65$ & 0 & Community & & Questionnaire & AHA-NHLBI & $<6$ & aRR 0.93 (0.73-1.19) \\
\hline & $(4.4)$ & Asia & & & & & & & & $7-8$ & Ref. \\
\hline & & & & & & & & & & $>8$ & aRR $0.93(0.60-1.53)$ \\
\hline \multirow[t]{3}{*}{ Song, $2016^{37}$} & Cohort & China & 11661 & $47.0 \pm 12.0$ & 82.1 & Hospital & & Questionnaire & AHA-NHLBI & $\leq 5.5$ & aHR $1.22(1.00-1.49)$ \\
\hline & (2) & Asia & & $18-98$ & & & & & & 7 & Ref. \\
\hline & & & & & & & & & & $\geq 8.5$ & aHR $1.24(0.93-1.66)$ \\
\hline \multirow[t]{3}{*}{ Deng, $2017^{12}$} & Cohort & Taiwan & 162121 & $20-80$ & 47.4 & Community & & Questionnaire & AHA-NHLBI & $<6$ & aHR $1.09(1.05-1.13)$ \\
\hline & (8) & Asia & & & & & & & & $6-8$ & Ref. \\
\hline & & & & & & & & & & $>8$ & aHR $0.93(0.88-0.99)$ \\
\hline \multirow[t]{2}{*}{ Itani, $2017^{38}$} & Cohort & Japan & 39182 & $42.4 \pm 9.8$ & 100 & Company & or & Questionnaire & Japanese criteria & $<5$ & aHR $1.08(1.03-1.14)$ \\
\hline & (7) & Asia & & $\geq 20$ & & office & & & & $\geq 5$ & Ref. \\
\hline & Cohort & China & 8969 & $56.7 \pm 7.7$ & 35 & Community & & Questionnaire & Chinese Criteria & $<6$ & aOR $1.25(0.752 .08)$ \\
\hline \multirow{2}{*}{$2020^{39}$} & (3) & Asia & & $35-75$ & & & & & & $7-8$ & Ref. \\
\hline & & & & & & & & & & $>9$ & aOR $0.96(0.69,1.33)$ \\
\hline
\end{tabular}


medRxiv preprint doi: https://doi.org/10.1101/2020.08.30.20184747; this version posted September 3, 2020. The copyright holder for this preprint (which was not certified by peer review) is the author/funder, who has granted medRxiv a license to display the preprint in perpetuity.

All rights reserved. No reuse allowed without permission.

10.2 Table 2. Subgroup meta-analysis of cross-sectional studies

301

\begin{tabular}{|c|c|c|c|c|c|c|c|c|}
\hline & \multicolumn{4}{|c|}{ Short sleep } & \multicolumn{4}{|c|}{ Long sleep } \\
\hline & No. & OR $(95 \% \mathrm{CI})$ & $\mathrm{I}^{2}$ & $\mathrm{P}_{\mathrm{Z}}^{\mathrm{a}}$ & No. & OR $(95 \% \mathrm{CI})$ & $\mathrm{I}^{2}$ & $\mathrm{P}_{\mathrm{z}}$ \\
\hline \multicolumn{9}{|l|}{ Gender } \\
\hline Men & 7 & $1.05(0.98,1.12)$ & 46.0 & Ref. & 7 & $1.03(0.99,1.08)$ & 14.0 & Ref. \\
\hline \multirow[t]{2}{*}{ Women } & 7 & $0.99(0.89,1.09)$ & 56.8 & 0.121 & 7 & $1.09(1.00,1.18)$ & 67.9 & 0.272 \\
\hline & & $\mathrm{P}=0.174^{\mathrm{b}}$ & & & & $\mathrm{P}=0.104$ & & \\
\hline \multicolumn{9}{|l|}{ Continent } \\
\hline Asia & 19 & $1.08(1.01,1.17)$ & 75.8 & Ref. & 20 & $1.12(1.05,1.20)$ & 79.0 & Ref. \\
\hline Europe & 6 & $1.03(0.98,1.08)$ & 20.8 & 0.271 & 6 & $1.17(1.01,1.36)$ & 64.6 & 0.583 \\
\hline North Europe & 5 & $1.31(0.99,1.74)$ & 24.5 & 0.205 & 4 & $1.22(0.75,2.00)$ & 15.0 & 0.736 \\
\hline South Europe & 1 & $1.70(1.19,2.44)$ & 0.0 & 0.016 & 1 & $1.08(0.92,4.26)$ & 0.0 & 0.147 \\
\hline \multirow[t]{2}{*}{ Africa } & 1 & $0.96(0.51,1.81)$ & 0.0 & 0.708 & & $\mathrm{P}=0.171$ & & \\
\hline & & $\mathrm{P}=0.173$ & & & & & & \\
\hline \multicolumn{9}{|l|}{ Study population } \\
\hline Community & 21 & $1.03(0.98,1.08)$ & 57.7 & Ref. & 22 & $1.14(1.07,1.21)$ & 65.9 & Ref. \\
\hline Hospital & 5 & $1.36(1.21,1.53)$ & 45.7 & $<0.001$ & 5 & $1.10(0.77,1.59)$ & 91.6 & 0.885 \\
\hline \multirow[t]{2}{*}{ Company or office } & 6 & $1.15(0.93,1.41)$ & 37.6 & 0.334 & 4 & $1.09(0.93,1.28)$ & 0.0 & 0.644 \\
\hline & & $\mathrm{P}<0.001$ & & & & $\mathrm{P}=0.261$ & & \\
\hline \multicolumn{9}{|l|}{ Sleep measurement } \\
\hline Questionnaire & 16 & $1.08(0.99,1.18)$ & 69.4 & Ref. & 15 & $1.11(1.03,1.20)$ & 87.6 & Ref. \\
\hline Interview & 8 & $1.13(1.04,1.23)$ & 76.3 & 0.496 & 8 & $1.12(1.01,1.24)$ & 36.6 & 0.893 \\
\hline Standard questionnaire & 6 & $1.02(0.92,1.13)$ & 0.0 & 0.363 & 6 & $1.13(0.90,1.40)$ & 81.1 & 0.947 \\
\hline \multirow[t]{2}{*}{ Objective } & 2 & $0.92(0.67,1.28)$ & 0.0 & 0.349 & 2 & $1.27(0.63,2.56)$ & 28.3 & 0.733 \\
\hline & & $\mathrm{P}=0.012$ & & & & $\mathrm{P}=0.021$ & & \\
\hline \multicolumn{9}{|l|}{ Definition of sleep duration } \\
\hline$<5$ for short or 9 for long & 5 & $1.23(0.98,1.5)$ & 29.2 & Ref. & 7 & $1.09(0.92,1.29)$ & 67.3 & Ref. \\
\hline$<6$ for short or for long & 13 & $1.13(1.02,1.24)$ & 82.4 & 0.492 & 17 & $1.18(1.09,1.27)$ & 53.6 & 0.405 \\
\hline$<7$ for short or for long & 2 & $1.04(0.98,1.11)$ & 20.4 & 0.164 & 6 & $1.01(0.92,1.11)$ & 93.0 & 0.464 \\
\hline \multirow[t]{2}{*}{$<8$} & 2 & $0.98(0.90,1.06)$ & 0.0 & 0.065 & & $\mathrm{P}=0.121$ & & \\
\hline & & $\mathrm{P}=0.154$ & & & & & & \\
\hline \multicolumn{9}{|l|}{ MetS measurement } \\
\hline NECP ATP-III & 12 & $1.06(0.98,1.16)$ & 68.2 & Ref. & 10 & $1.07(0.98,1.15)$ & 73.8 & Ref. \\
\hline Modified NECP ATP-III & 6 & $1.00(0.94,1.07)$ & 34.3 & 0.308 & 6 & $1.22(1.15,1.28)$ & 35.8 & 0.006 \\
\hline AHA-NHLBI & 9 & $1.20(1.03,1.39)$ & 44.3 & 0.186 & 9 & $1.23(1.01,1.50)$ & 27.3 & 0.195 \\
\hline IDF & 3 & $1.05(0.88,1.25)$ & 21.0 & 0.879 & 5 & $1.07(1.01,1.14)$ & 33.4 & 0.945 \\
\hline \multirow[t]{2}{*}{ Others } & 2 & $1.40(1.22,1.61)$ & 14.1 & $<0.001$ & 1 & $0.98(0.81,1.19)$ & 10.1 & 0.426 \\
\hline & & $\mathrm{P}<0.001$ & & & & $\mathrm{P}<0.001$ & & \\
\hline
\end{tabular}


medRxiv preprint doi: https://doi.org/10.1101/2020.08.30.20184747; this version posted September 3, 2020. The copyright holder for this preprint (which was not certified by peer review) is the author/funder, who has granted medRxiv a license to display the preprint in perpetuity. All rights reserved. No reuse allowed without permission.

304 Table 2-Continued Subgroup meta-analysis of cross-sectional studies

305

\begin{tabular}{|c|c|c|c|c|c|c|c|c|}
\hline & \multicolumn{4}{|c|}{ Short sleep } & \multicolumn{4}{|c|}{ Long sleep } \\
\hline & No. & OR $(95 \% \mathrm{CI})$ & $\mathrm{I}^{2}$ & $\mathrm{P}_{\mathrm{z}}$ & No. & OR $(95 \%$ CI $)$ & $\mathrm{I}^{2}$ & $\mathrm{P}_{\mathrm{z}}$ \\
\hline \multicolumn{9}{|l|}{ Sample size } \\
\hline$<5000$ & 23 & $1.07(0.99,1.06)$ & 49.7 & Ref. & 18 & $1.28(1.12,1.47)$ & 56.2 & Ref. \\
\hline 5000-20000 & 5 & $1.09(0.96,1.25)$ & 57.4 & 0.842 & 8 & $1.05(0.95,1.15)$ & 82.0 & 0.018 \\
\hline \multirow[t]{2}{*}{$>20000$} & 4 & $1.11(1.00,1.23)$ & 51.3 & 0.638 & 5 & $1.09(1.01,1.18)$ & 82.1 & 0.044 \\
\hline & & $\mathrm{P}=0.004$ & & & & $\mathrm{P}<0.001$ & & \\
\hline \multicolumn{9}{|l|}{ Study quality } \\
\hline High & 7 & $1.03(1.00,1.06)$ & 26.9 & Ref. & 7 & $1.03(0.97,1.09)$ & 60.5 & Ref. \\
\hline Low & 25 & $1.06(1.03,1.09)$ & 63.4 & 0.013 & 23 & $1.15(1.06,1.25)$ & 70.7 & 0.030 \\
\hline & & $\mathrm{P}=0.143$ & & & & $\mathrm{P}<0.001$ & & \\
\hline
\end{tabular}

${ }^{\mathrm{a}} \mathrm{P}$ value of two sample $\mathrm{z}$-test for estimates between subgroups.

${ }^{\mathrm{b}} \mathrm{P}$ for heterogeneity.

308

309

310

311

312

313

314

315

316

317

318

319

320

321

322

323

324

325

326

327

328

329

330

331 
medRxiv preprint doi: https://doi.org/10.1101/2020.08.30.20184747; this version posted September 3, 2020. The copyright holder for this preprint (which was not certified by peer review) is the author/funder, who has granted medRxiv a license to display the preprint in perpetuity.

All rights reserved. No reuse allowed without permission.

\begin{tabular}{lllll}
\hline & \multicolumn{3}{l}{ Short sleep duration } \\
\hline & Univariable analysis & \multicolumn{2}{l}{ Multivariable analysis } \\
& Coef. & P value & Coef. & P value \\
\hline Mean age, years & $-0.01(-0.02,-0.01)$ & 0.020 & $-0.01(-0.01,0.00)$ & 0.086 \\
Proportion of males, \% & $0.08(-0.10,0.27)$ & 0.356 & $-0.05(-0.23,0.14)$ & 0.622 \\
Definition of short/long sleep & $-0.07(-0.15,0.01)$ & 0.099 & $-0.08(-0.15,-0.12)$ & 0.011 \\
Sample size & $0.01(-0.08,0.09)$ & 0.864 & $0.01(-0.09,0.09)$ & 0.351 \\
Study quality & $-0.15(-0.30,0.00)$ & 0.039 & $-0.26(-0.61,0.09)$ & 0.149 \\
\hline & & Long sleep duration & \\
\hline & Univariable analysis & Multivariable analysis \\
& Coef. & P value & Coef. & P value \\
\hline Mean age, years & $0.00(0.00,0.01)$ & 0.113 & $0.00(-0.00,0.01)$ & 0.720 \\
Proportion of males, \% & $0.01(-0.18,0.02)$ & 0.891 & $-0.04(-0.44,0.35)$ & 0.828 \\
Definition of short/long sleep & $-0.16(-0.33,0.10)$ & 0.776 & $-0.09(-0.28,0.10)$ & 0.958 \\
Sample size & $-0.09(-0.18,0.00)$ & 0.056 & $-0.08(-0.25,0.08)$ & 0.318 \\
Study quality & $-0.01(-0.14,0.10)$ & 0.807 & $0.01(-0.50,0.52)$ & 0.360 \\
\hline
\end{tabular}


medRxiv preprint doi: https://doi.org/10.1101/2020.08.30.20184747; this version posted September 3, 2020. The copyright holder for this preprint (which was not certified by peer review) is the author/funder, who has granted medRxiv a license to display the preprint in perpetuity.

All rights reserved. No reuse allowed without permission.

353 Figure 1. Flowchart for the included studies.

354 Figure 2. Forest plot of association between sleep duration and the risk of metabolic syndrome.

355 (A) Comparing short sleepers with normal sleepers; (B) Comparing long sleepers with normal 356 sleepers.

357 Figure 3. Forest plot of association between sleep duration and the prevalence of metabolic

358 syndrome. (A) Comparing short sleepers with normal sleepers; (B) Comparing long sleepers with 359 normal sleepers.

360

361

362

363

364

365

366

367

368

369

370

371

372

373

374

375

376

377

378

379

380

381

382

383

384

385

386

387

388

389 


\section{References}

391 1. Isomaa B, Almgren P, Tuomi T, et al. Cardiovascular morbidity and mortality associated with the 392 metabolic syndrome. Diabetes Care 2001; 24(4): 683-9.

393 2. Daly CA, Hildebrandt P, Bertrand M, et al. Adverse prognosis associated with the metabolic syndrome 394 in established coronary artery disease: data from the EUROPA trial. Heart 2007; 93(11): 1406-11.

395 3. Aguilar M, Bhuket T, Torres S, Liu B, Wong RJ. Prevalence of the metabolic syndrome in the United 396 States, 2003-2012. JAMA 2015; 313(19): 1973-4.

397 4. Di Marzo V, Silvestri C. Lifestyle and Metabolic Syndrome: Contribution of the Endocannabinoidome. 398 Nutrients 2019; 11(8).

399 5. Krittanawong C, Tunhasiriwet A, Wang Z, et al. Association between short and long sleep durations 400 and cardiovascular outcomes: a systematic review and meta-analysis. Eur Heart $J$ Acute Cardiovasc Care $401 \quad 2019 ; 8(8):$ 762-70.

402 6. Jike M, Itani O, Watanabe N, Buysse DJ, Kaneita Y. Long sleep duration and health outcomes: A 403 systematic review, meta-analysis and meta-regression. Sleep Med Rev2018; 39: 25-36.

$4047 . \quad J u$ SY, Choi WS. Sleep duration and metabolic syndrome in adult populations: a meta-analysis of 405 observational studies. Nutr Diabetes 2013; 3: e65.

406 8. Iftikhar IH, Donley MA, Mindel J, Pleister A, Soriano S, Magalang UJ. Sleep Duration and Metabolic 407 Syndrome. An Updated Dose-Risk Metaanalysis. Ann Am Thorac Soc 2015; 12(9): 1364-72.

408 9. XI B. Short sleep duration predicts risk of metabolic syndrome: A systematic review and meta-analysis. 4092014.

410 10. Karen Grace-Martin AG. Cohort and Case-Control Studies: Pro's and Con's. 2017; 411 https://www.theanalysisfactor.com/cohort-and-case-control-studies-pros-and-cons/.

412 11. Setia MS. Methodology Series Module 3: Cross-sectional Studies. Indian J Dermato/2016; 61(3): 2614134.

414 12. Deng HB, Tam T, Zee BC, et al. Short Sleep Duration Increases Metabolic Impact in Healthy Adults: A 415 Population-Based Cohort Study. Sleep 2017; 40(10).

416 13. Grant RL. Converting an odds ratio to a range of plausible relative risks for better communication of 417 research findings. BMJ 2014; 348: 77450.

418 14. Adenekan B, Pandey A, McKenzie S, Zizi F, Casimir GJ, Jean-Louis G. Sleep in America: role of 419 racial/ethnic differences. Sleep Med Rev2013; 17(4): 255-62.

420 15. Wells G SB, O'Connell D, Peterson J, Welch V, Losos M. The Newcastle-Ottawa Scale (NOS) for 421 assessing the quality of nonrandomised studies in meta-analyses. 2014; 422 http://www.ohri.ca/programs/clinical_epidemiology/oxford.asp.

423 16. Higgins JP, Thompson SG, Deeks JJ, Altman DG. Measuring inconsistency in meta-analyses. BMJ 424 2003; 327(7414): 557-60.

425 17. Egger M, Davey Smith G, Schneider M, Minder C. Bias in meta-analysis detected by a simple, 426 graphical test. BMJ 1997; 315(7109): 629-34.

427 18. Begg CB, Mazumdar M. Operating characteristics of a rank correlation test for publication bias. 
medRxiv preprint doi: https://doi.org/10.1101/2020.08.30.20184747; this version posted September 3, 2020. The copyright holder for this preprint (which was not certified by peer review) is the author/funder, who has granted medRxiv a license to display the preprint in perpetuity.

All rights reserved. No reuse allowed without permission.

Biometrics 1994; 50(4): 1088-101.

19. Duval S, Tweedie R. Trim and fill: A simple funnel-plot-based method of testing and adjusting for publication bias in meta-analysis. Biometrics 2000; 56(2): 455-63.

20. W. V. Conducting meta-analyses in R with the metafor package. J Stat Softw 2010; 2010; 36: 1-48.

21. Zhang Tiansong ZS. How to compare summary estimates of different subgroups in meta-analysis.

Chinese Journal of Evidence-Based Medicine 2017;

https://www.ixueshu.com/document/be6c862ae782c141182f500f64e4272a318947a18e7f9386.html.

22. Smiley A, King D, Bidulescu A. The Association between Sleep Duration and Metabolic Syndrome: The NHANES 2013/2014. Nutrients 2019; 11(11).

23. Spiegel K, Leproult R, Van Cauter E. Impact of sleep debt on metabolic and endocrine function. Lancet 1999; 354(9188): 1435-9.

24. Zimberg IZ, Damaso A, Del Re M, et al. Short sleep duration and obesity: mechanisms and future perspectives. Cell Biochem Funct 2012; 30(6): 524-9.

25. Meier-Ewert HK, Ridker Pm Fau - Rifai N, Rifai N Fau - Regan MM, et al. Effect of sleep loss on Creactive protein, an inflammatory marker of cardiovascular risk. 2004

; (0735-1097 (Print)).

26. Grandner MA, Drummond SP. Who are the long sleepers? Towards an understanding of the mortality relationship. Sleep Med Rev2007; 11(5): 341-60.

27. Stranges S, Dorn JM, Shipley MJ, et al. Correlates of short and long sleep duration: a cross-cultural comparison between the United Kingdom and the United States: the Whitehall II Study and the Western New York Health Study. Am J Epidemio/ 2008; 168(12): 1353-64.

28. Allebrandt KV, Teder-Laving M, Akyol M, et al. CLOCK gene variants associate with sleep duration in two independent populations. Biol Psychiatry2010; 67(11): 1040-7.

29. Lemmer B, Oster H. The Role of Circadian Rhythms in the Hypertension of Diabetes Mellitus and the Metabolic Syndrome. Curr Hypertens Rep 2018; 20(5): 43.

30. Kraemer HC, Kazdin AE, Offord DR, Kessler RC, Jensen PS, Kupfer DJ. Coming to terms with the terms of risk. Arch Gen Psychiatry 1997; 54(4): 337-43.

31. Buysse DJ. Sleep health: can we define it? Does it matter? Sleep 2014; 37(1): 9-17.

32. Choi JK, Kim MY, Kim JK, et al. Association between short sleep duration and high incidence of metabolic syndrome in midlife women. Tohoku J Exp Med 2011; 225(3): 187-93.

33. Otsuka T, Kawada T, Yanai M, Kitagawa Y, Kan H. [Incidence of metabolic syndrome and associated lifestyle factors in a worksite male population]. Sangyo Eiseigaku Zasshi2011; 53(3): 78-86.

34. Chaput JP, McNeil J, Despres JP, Bouchard C, Tremblay A. Short sleep duration as a risk factor for the development of the metabolic syndrome in adults. Prev Med 2013; 57(6): 872-7.

35. Kim JY, Yadav D, Ahn SV, et al. A prospective study of total sleep duration and incident metabolic syndrome: the ARIRANG study. Sleep Med 2015; 16(12): 1511-5.

36. Li X, Lin L, Lv L, et al. U-shaped relationships between sleep duration and metabolic syndrome and metabolic syndrome components in males: a prospective cohort study. Sleep Med2015; 16(8): 949-54. 
medRxiv preprint doi: https://doi.org/10.1101/2020.08.30.20184747; this version posted September 3, 2020. The copyright holder for this preprint (which was not certified by peer review) is the author/funder, who has granted medRxiv a license to display the preprint in perpetuity.

All rights reserved. No reuse allowed without permission.

466 37. Song Q, Liu X, Zhou W, Wang X, Wu S. Changes in sleep duration and risk of metabolic syndrome:

467 the Kailuan prospective study. SciRep 2016; 6: 36861.

468 38. Itani O, Kaneita Y, Tokiya M, et al. Short sleep duration, shift work, and actual days taken off work are

469 predictive life-style risk factors for new-onset metabolic syndrome: a seven-year cohort study of 40,000 male

470 workers. Sleep Med 2017; 39: 87-94.

471 39. Ye Y, Zhang L, Wang A, et al. Association of sleep duration with stroke, myocardial infarction, and 472 tumors in a Chinese population with metabolic syndrome: a retrospective study. Lipids Health Dis 2020; 19(1):

473155.

474 


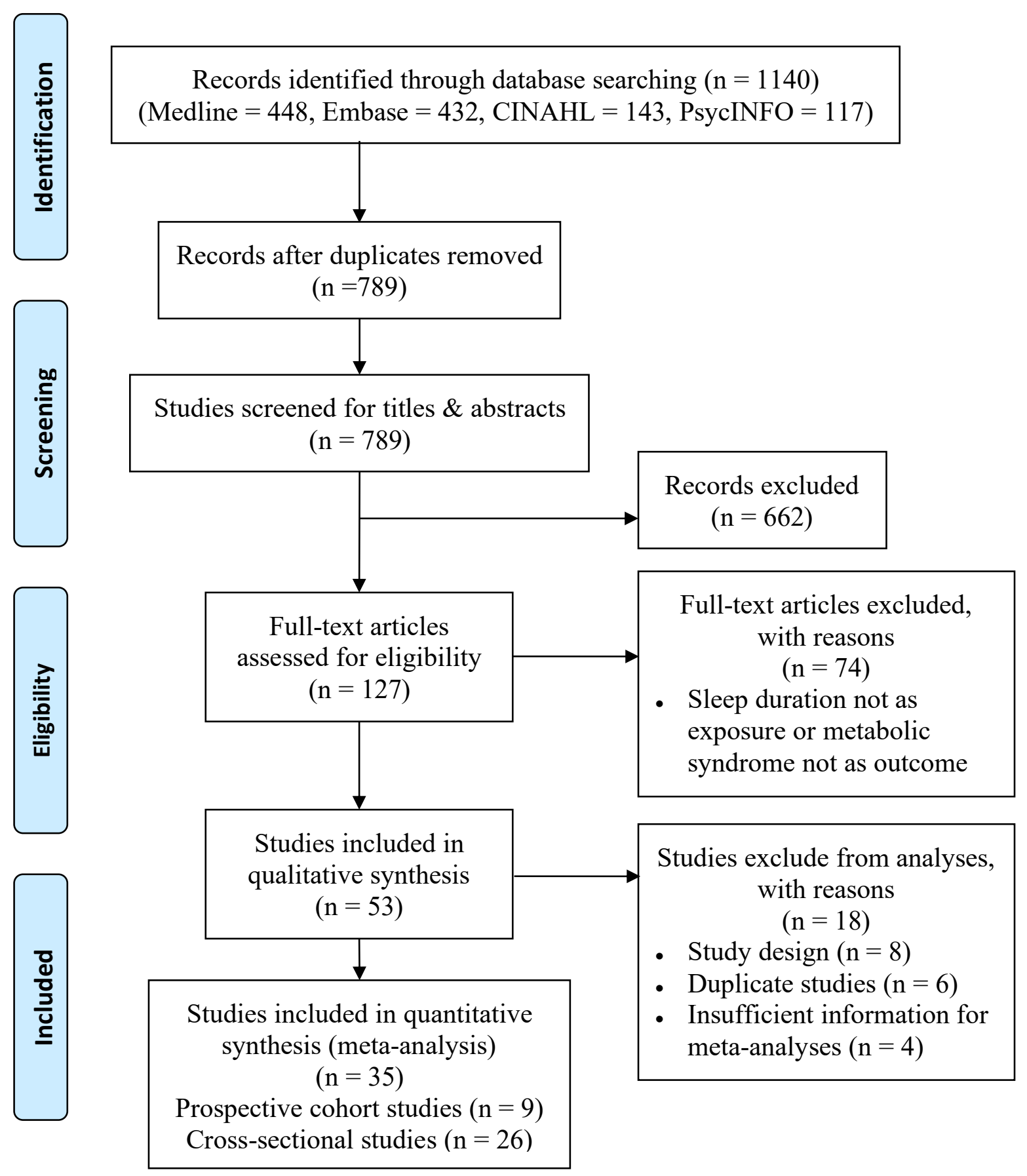


Choi JK men (2011)

Choi JK women (2011)

Otsuka T. (201 1)

Chaput J. (2013)

Kim J.Y. (2015)

LiX. men (2015)

L.i X. women (20!5)

Song O. (2016)

Deng H.B. (2017)

Itani O. (2017)

Yingnan Y.E. (2020)

Overall (I-squared $-63,6 \%, p=0,002)$

NOTE: Weights are from random effects analysis

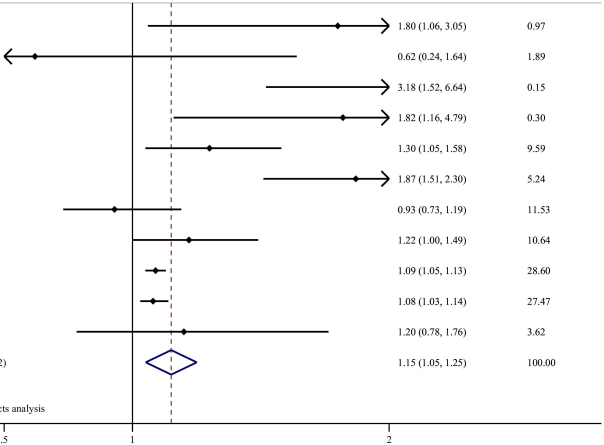




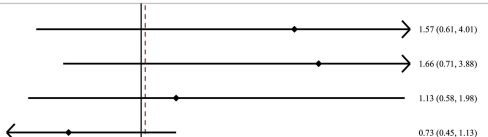

Li X. men (2015)

LiX. women (2015)

Song Q. (2016)

Deng H.B. $(2017)$

Yingnan Y.E. (2020)

Overall $(I-$-squared $=38.0 \%, p=0.115)$

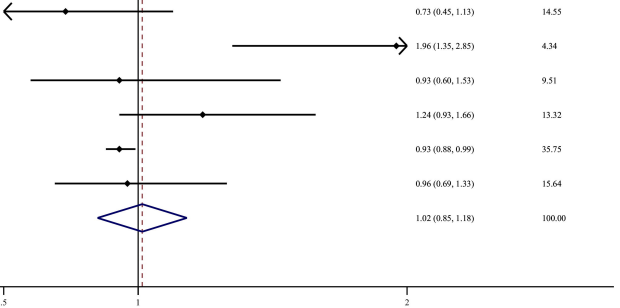


Santas A.C. (2007)

Santas A.C. (2007)

Choi KM (2008)

Hall MH (2008)

Aroar T. (2011)

Kobayashi D. (2011)

Najafian J. (2011)

McCanlies E.C. (2012)

Sabanayagam C. (2012)

Wu M. (2012)

Wu M. (2012)

Hung H.C. (2013)

Yoo H. (2013)

Okubo N. (2014)

Saleh D. (2014)

Yu S. men (2014)

Yu S. women (2014)

Canuto R. (2015)

Chang J.H. (2015)

Wu J. men (2015)

Wu J. women (2015)

Lin S.C. (2016)

Min H. (2016)

Cole H.V. (2017)

Suliga E. (2017)

Suliga E. (2017)

Kaira C. (2018)

Kim C.E. (2018)

Kim C.E. (2018)

Ostadrahimi A. (2018)

Titova O.G. (2018)

Qian Y.X. (2019)

Overall $(\mathrm{I}$-squared $=66.5 \%, \mathrm{p}=0.000)$

NOTE: Weights are from random effects analysis

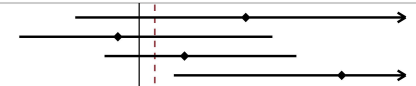

$1.40(0.76,2.60)$

0.31

$0.92(0.55,1.50)$

1.06

$1.17(0.87,1.59)$

1.68

$1.76(1.13,2.74)$

0.40

$0.97(0.88,1.06)$

6.47

$1.40(1.21,1.60)$

3.80

$1.52(1.33,1.74)$

3.60

$2.30(0.45,6.50)$

0.03

$1.24(0.98,1.57)$

2.27

$1.28(1.01,1.63)$

2.11

$1.04(0.72,1.51)$

1.45

$1.02(0.56,1.48)$

1.12

0.02

0.01

$1.20(0.13,10.91)$

1.72

$0.91(0.62,1.33)$

5.23

$0.99(0.90,1.09)$

6.33

$1.70(1.09,2.24)$

0.75

$1.04(0.51,2.13)$

0.40

$1.04(0.93,1.17)$

5.64

$0.93(0.79,1.10)$

4.71

$1.54(1.05,2.47)$

0.51

$0.75(0.59,0.85)$

5.36

$0.96(0.39,1.38)$

0.99

$0.99(0.91,1.07)$

6.74

$1.00(0.94,1.08)$

7.00

$0.96(0.70,1.30)$

2.21

$1.12(1.05,1.19)$

7.00

$1.05(1.00,1.10)$

7.45

$0.97(0.85,1.10)$

5.50

$1.08(1.03,1.13)$

7.45

$1.59(1.10,2.33)$

0.67

$1.06(1.01,1.11)$

100.00 
Santas A.C. men (2007)

Santas A.C. women (2007)

Choi KM (2008)

Hall MH (2008)

Aroar T (2011)

Kobayashi D. (2011)

Najafian J. (2011)

Sabanayagam C. (2012)

Wu M. men (2012)

Wu M. women (2012)

Hung H.C. (2013)

Yoo H. (2013)

Saleh D. (2014)

Yu S. men (2014)

Yu S, women (2014)

Chang J.H. men (2015)

Wu J. men (2015)

Wu J. women (2015)

Lin S.C. (2016)

Min H. women (2016)

Xiao J. men (2016)

Xiao J. women (2016)

Cole H.V. (2017)

Suliga E. men (2017)

Suliga E. women (2017)

Kaira C. (2018)

Kim C.E. men (2018)

Kim C.E. women (2018)

Ostadrahimi A. (2018)

Titova O.G. (2018)

Qian Y.X. (2019)

Overall (I-squared $=73.8 \%, p=0.000)$

NOTE: Weights are from random effects analysis

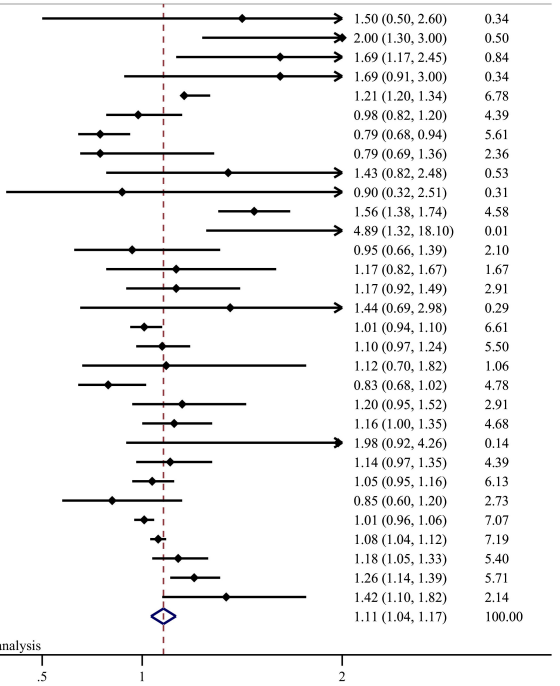

